\title{
The Formation of Legal Framework of Migration Policy in Russian Federation (1992-2010)
}

\author{
Albina R. Fayzullina ${ }^{1}$ \\ ${ }^{1}$ Kazan (Volga Region) Federal University, Kazan, Russia \\ Correspondence: Albina R. Fayzullina, Kazan (Volga Region) Federal University, 420008, Kazan, Kremlyovskaya \\ Street 18, Russia. E-mail: fazalbina@rambler.ru
}

Received: June 2, 2015 Accepted: June 15, 2015 Online Published: June 29, 2015

doi:10.5539/jsd.v8n5p12 URL: http://dx.doi.org/10.5539/jsd.v8n5p12

\begin{abstract}
The relevance of the issue under examination is conditioned by the significance and necessity of research on the process of formation of the migration policy legal framework in the state administration applied to the solution of arising problems in the field of political and legal regulation of migration processes. The article is aimed at the study of the regulatory framework formation of the state migration policy in the Russian Federation during the period of 1992 to 2010 years. The leading approach to the research on the given problem is institutional approach, which allows us to research the legal institution of migration processes - an important aspect of migration policy. The article sheds light on the migration policy development trends, shows the process of formation of new migration policy, gives the analysis of its regulatory framework and the influence of the country's political situation on changes in legislative measures in the field of migration processes regulation, and suggests recommendations on their optimization. The materials, observations, and conclusions provided by this article contribute to the theory of political regulation of migration processes and can prove useful in adopting managerial decisions and holding organizational events for purposes of efficiency enhancement of migration processes regulation, as well as in developing curricula on politological specialties: "Political Region Studies", "Political Management" and others, in delivering lectures on "Migration Policy" course.
\end{abstract}

Keywords: migration policy, migration processes, forced migrants, migration legislation, regulatory framework

\section{Introduction}

At the end of the XXth century Russia became a center of attraction for emigrational flows of the ethnical Russian as well as of representatives of the Titular nations of the former soviet republics. Moreover, it faced for the first time the problem of mass forced migration. These phenomena demanded the renovation of the regulatory and legislation framework of the migration policy.

As a result of the social-economic development (Rybakovskiy, 1987) and social-political instability, migration can favour the improvement of the economic and social conditions on the one hand, while on the other hand it may exacerbate the inequality and provoke a new flow of the social and political tension. The development of the events according to one or the other variant depends on the character of the migration itself, the governmental activity, and laws regulating the movements of the people (Fayzullina, 2007).

Migration policy is aimed at regulating the number and structure of the commonwealth and separate regions through influencing the migration flows. (Zayonchkovskaya, 1997). While protecting its interests, the state always heads to the control of migration: stimulating the flow of the workforce, when there is a shortage, limiting the entrance to the country for the work migrants who are striving for expanding their living space and fill the labour market, which leads to the difficulties for the Russian to get a job. The present legal and institutional instruments and mechanisms which were effective in the past seem to be inadequate in the conditions of the contemporary migration (Yunusova, 2014; Fayzullina, 2015).

The absence of the regulatory legal acts, settling the correlation between the migrants and the state bodies, enterprises and organizations, citizens of the Russian Federation, leads to a legal vacuum. Migration processes at the beginning of the 1990-s were spontaneous with the minimal control from the state bodies (Fayzullina, 2006). Prevention of the forced migration of the population, putting in order the labour, internal and external migration, suppression of the negative tendencies of the illegal migration as well as a fight with it - these are the most 
important objectives of the Russian migration policy. Regulatory laws must settle not only the questions of the social adaptation of the migrants in their new place of living but also the problems connected with the first two steps of the migration process: the decision-making about migration and immediate territorial relocation.

Above all this, the system of measures included in the migration policy of the Russian Federation, must be within the legislation framework not only of the Russian laws but also of the international acts, regulating the migration processes.

All this makes relevant the problem of studying the processes of the formation of the regulatory framework of the state migration policy.

\section{Methodological Framework}

\subsection{Problems of the Research}

In the course of research it was necessary to solve the following problems:

- explain necessity of working out new migration policy and characterize its main course

- analyze the process of formation of the normative framework of the state migration policy

\subsection{Theoretical and Methodological Framework of Research}

The basis for theoretical and methodological framework of research was conceptual positions of political science related to the definition of such concepts as political system, political process, political environment and also scientific research in the field of migration processes. For analyzing the defined problem institutional, structural and functional approaches were used as well as general scientific and special methods consisting of tools of political science, in particular: comparative and contrastive. Complex approach to the research of the existing problem made it necessary to apply empirical methods of research: statistic method, questionnaire survey, analysis of documents. Historical method promoted the subject of research consideration in development.

\subsection{Regulatory Framework of the Research}

The regulatory framework of the research consists of Constitution and laws of the Russian Federation, the RF President Decrees, decisions and orders of the Russian Government, regulatory legal acts of the RF units, published documents of government bodies and those of the state migration policy.

\section{Results}

The absence of regulatory legal acts settling the relations of migrants with government bodies, enterprises and organizations, citizens of the RF, entailed a legal vacuum in this area. In this regard, migration processes were held spontaneously, with minimum supervision of government bodies. The prevention of the forced migration, regulating of labor, internal and external migration, suppression and combating negative tendencies of illegal migration are the most important tasks of the Russian migration policy. According to the author, the regulatory laws must reflect not only the issues of social adaptation of migrants to the new location, but also the problems associated with the first two stages of the migration process: the decision to migrate and the direct territorial movement.

The new legislation framework of the state policy in the sphere of regulation of migration processes ("Refugees Law" and "Forced Migrants Law") was to dramatically improve the situation of different categories of migrants, but not complicate them. These laws formed the basis of the regulatory framework of the migration policy formation in Russia. In succeeding years the current legislation was revised, but only for two categories of migrants - forced migrants and refugees.

It should be noted that the legislative framework of migration policy of the Russian Federation was formed in a very short period of time, which explains imperfection of regulatory framework laws.

The Russian Federation has become a member of most international agreements in varying degrees, affecting the migration and freedom of movement.

In accordance with part 4 of article 15 of the Constitution, the Russian Federation recognizes the primacy of international law over national law. "The commonly recognized principles and norms of international law and international treaties of the Russian Federation are an integral part of its legal system. If international agreement of the Russian Federation establishes other than provided by law rules, the rules of the international agreement are applied." (The Constitution of the Russian Federation, 2003). In accordance with this, the modern regulatory legal acts are based on the relevant international legal documents.

Regulatory framework formation of the state migration policy in Russian Federation started with the adoption of 
the Convention on the Status of Refugees and of Protocol. The first step in legal relationship regulation related to migration exchange was the adoption of two laws by the Russian Federation on February 19, 1993 «On Refugees» (Law of the Russian Federation from 19.02.1993 №4528-I «On Refugees», 1993) and «On Forced Migrants» (Law of the Russian Federation 19.02.1993 № 4530-I «On Forced Migrants»), which established the prerequisites for legal regulation of public relations. These laws being the basis of the regulatory framework of the migration policy formation in Russia gave the definition of "refugee" and "forced migrant" and determined their legal status.

Within the CIS framework, on September 24, 1993 the CIS members signed the Agreement on assistance to refugees and forced migrants (the Agreement on assistance to refugees and forced migrants, from September 24, 1993, 1999). For the first time the Agreement introduced the term "forced migrant". In the international regulatory legal acts this term was not previously used. Under the term "forced migrant", we understand "a person who due to circumstances is forced to return to the country, he belongs to as a citizen".

This category of persons is officially excluded from the 1951 Convention (Convention relating to the Status of Refugees, 1996). The concept of internally displaced persons is of limited use in the CIS, and in the modern theory of international law is non-existent. Instead of the term "forced migrant" the term "internally displaced person" is used, which, in turn, is not defined in Russian legislation.

Displaced persons were divided into refugees and forced migrants on the principle of citizenship: refugee is a person who does not possess Russian citizenship; forced migrant is a person who is a citizen of the RF, permanently living in the territory of the Russian Federation. The differentiation of priorities of the Russian political system with respect to the categories of forced migrants lies in the division between refugees and internally displaced persons.

Refugees as distinct from forced migrants cannot «be employed or carry on business, acquire ownership of real estate under the terms established by the legislation for foreign citizens of the Russian Federation» (Law of the Russian Federation from February 19 1993, № 4528-I «On Refugees», 1993), although «a recognized refugee ranks as a citizen of the Russian Federation» (Law of the Russian Federation from February 19 1993, № 4528-I «On Refugees», 1993).

Forced migrants have the right to be included in the list of citizens which according to the legislation of the Russian Federation are entitled for top-priority getting (purchase) of housing from public housing by national regulatory and administrative authorities» (Law of the Russian Federation from February 191993 № 4530-I «On Forced Migrants», 1993). Public authorities are obliged to «provide preferential loans» for private housing construction including the obtainment of land lot and construction materials. Refugees do not have this right. Public authorities are obliged to «assess in placement of forced migrant's child into public or municipal preschool educational institutions, and in transfer of pupils and students to the institutions of secondary and higher vocational education» (Law of the Russian Federation of February 191993 № 4530-I «On Forced Migrants», 1993), whereas it does not cover refugees.

The law allows the recognition of foreign citizen as forced migrant or stateless persons permanently residing lawfully in the territory of the Russian Federation who changed the place of residence within the territory of the Russian Federation. However, exit due to famine, epidemics, catastrophes, natural disasters forcing to leave all the previous place of residence is not recognized by law as the basis on which the person is entitled to the status of forced migrant. The lack of appropriate status in these categories of citizens creates considerable difficulties in the places of their immigration. The same can be said of the forced migrants who left Russia and were going to return.

In our view, the division of the displaced persons into refugees and forced migrants allowed to separate the latter as citizens of the former Soviet Union capable of integration into the Russian society of migrants from abroad.

In the new migration situation it was important to determine how to organize the flow of migrants, to make the system more democratic and integrated, to ensure permanent or temporary protection of different categories of internally displaced persons in accordance with their real needs.

In this regard, there was need to develop a mechanism of the Russian Federation state authority bodies interaction with migrants arriving on its territory. The first example of such a mechanism is the "Regulations on the procedure for recognition of forced migrants, their registration and accounting in the Russian Federation", approved by the Russian Federal Migration Service on May 25, 1993 № 2775 (Refugees and Forced Migrants Compass, 1995). This Regulation establishes the range of documents necessary for the submission of the person who applied for recognition as a displaced person: passport, birth certificate, marriage certificate, pension 
certificate, etc., as well as "a proof of violence towards him or his family or of any other form of persecution or real risk of persecution on the grounds and circumstances referred to in the Article 1 of the Law "On Forced Migrants" (Refugees and Forced Migrants Compass, 1995).

Forced migrant status involves performing certain procedures aimed at determining person's validity of claims to this status. In other words, the forced migrant status is made dependent on the ability of addressee to give such evidence.

A significant role in the regulation of migration processes is the new Federal Law "On Citizenship of the Russian Federation." It allows the granting of citizenship of foreign nationals and stateless persons who have lived in the territory of the Russian Federation before handling application for citizenship for five years continuously (Article 13, Part. 1-a), and the ability of the applicants to exit the Russian Federation for up to three months during one year. The norm for citizenship by registration order is not available.

Mandatory requirement is the command of the language and a legitimate source of livelihood. The list of grounds for the rejection of applications for citizenship is extended, for example, now it has a provision that allows to reject the petition of those who were previously convicted; a foreign national must also renounce the existing citizenship. This law leads to a reduction of persons with dual citizenship, in the absence of relevant international agreements (Law of the Russian Federation from 31.05.2002 № 62 - Federal Law "On Citizenship of the Russian Federation", 2002).

For our study it is important to consider another aspect of the problem associated with the increase in the inflow of forced migrants. The massive influx of migrants has led to a sharp increase in the cost of their reception and settlement, increased competition in the labor market, increased pressure on free field of social services and the deterioration of the crime situation. All this has caused mass discontent of the local population and caused the emergence of negative attitudes towards migrants (Drobizheva, 1998).

The increasing flow of migrants is ahead of government's ability to regulate migration processes and respond to their consequences. Therefore, the main issue of a competent immigration policy is the development of a complex of measures on suppression of illegal entry into the country of foreign citizens, committed in violation of the legislation on the entry and transit of foreigners.

Illegal migration, with the cross-border nature, is becoming more and more international criminal activity, hampering economic and social development of the state and its sovereignty. It is one of the main reasons for the increase in the smuggling of goods, weapons, illegal drug trafficking, expansion of the shadow labor market, the spread of dangerous infectious diseases that entail the emergence of tensions in international relations and represents a threat to the national security of the state.

The Russian Federation law "On the state policy of the Russian Federation in respect of compatriots abroad" (the Russian Federation Law "On the state policy of the Russian Federation in respect of compatriots abroad" from 24.05 1999. No. 99-FZ, 1999) is aimed to protect the interests of citizens of the former Soviet Union who have experienced discrimination on ethnic grounds, and of "stateless persons", which became the Russian-speaking population in several former Soviet republics.

But this law has several disadvantages: gives a fuzzy definition of "compatriot", does not give nationals real guarantees of state aid or resettlement to Russia or staying in the States - the former republics of the USSR. Issuance of certificates "compatriots" can be considered as a case of dual citizenship or could be considered by their States of residence as interference in their internal Affairs. This law intrudes upon the actions of other normative acts: the law "On citizenship of the Russian Federation", "On the procedure for exit from the Russian Federation and entry into the Russian Federation". In fact, the law is an abstract Declaration of the rights and freedoms of Russian citizens and former citizens of the USSR abroad. It was not in a position to implement what was intended: to contribute to the growth of immigration of these individuals.

Migration is an important resource in solving demographic and labor problems in Russia. Ensuring safety of the population in important geopolitical regions of the Russian Federation, including attracting compatriots, who are highly qualified specialists and creating conditions for their return to the Russian Federation, is one of the main tasks in the field of demographic development.

Russian reality confirms the limitations of the legal field of modern legislation. It is necessary to expand the legal framework and the definition of new categories of forced migrants, which should also be provided with a differentiated state support.

We should point out the most acute problems in the legislative regulation of migration processes: uncertainty of the legal status of foreign citizens and stateless persons in the Russian Federation; the lack of a legal mechanism, 
the criteria allowing them to stay in the territory of the Russian Federation and the residence permit.

One of the major drawbacks of the Russian legal system is a big time gap between the adoption of the law on the one hand, and the necessary regulations on the other. A consequence of the lack of a full legal analysis of the legislation is the adoption of the regional illegal acts.

The general analysis of the migration legislation in the Russian Federation has allowed to come to a number of conclusions. In the last decade of the twentieth century and the first years of the twenty-first century in the difficult conditions of reforming the socio-political system in Russian Federation it was established the legal framework of migration policy, what allowed to control migration flows and it has a tendency to develop. Russia refused from soft migration policy towards refugees, which was carried out from 1992 and led to the uncontrolled illegal immigration, and is inclined to a more stringent immigration policy. The approach is broadly consistent with international standards and international obligations taken over by the Russian Federation.

During this period, some experience of working with migrants, including negative one was gained. The current legislation is characterized by inconsistency, fragmentation. The existing laws are constantly amended, which complicates the work of state bodies and misleads migrants seeking to obtain the status of refugee or internally displaced persons. A number of regulations is declarative and contradictive with the provisions of other laws. In practice, this leads to the fact that the current legislation does not establish an effective legal mechanism for regulating migration and combating illegal migration.

According to the author, the present legislation, regulating the rights of migrants requires significant changes. In order to improve the efficiency of the state migration policy a systematic approach to addressing migration issues is required, including the regulation of the legal framework of the total migration flows.

Analysis of legislative acts shows that the problems relating the legislative consolidation of the concept of "worker" and its legal status, the concepts of "forced migration", "external labor migration", "illegal migration" are solved insufficiently, the legal status of public organizations, forms of their activity, the possibility over public control over the activity of state bodies is not defined.

Decrees of the Russian Federation President "On measures for rendering assistance to voluntary resettlement to the Russian Federation of the compatriots living abroad (from June 22, 2006 No. 637), "Issues of the interdepartmental commission on realization of a state program on rendering assistance to voluntary resettlement to the Russian Federation of the compatriots living abroad"(from 01.08.2006 No. 814), numbers of the Resolutions of the Government of the Russian Federation adopted on the basis of these Decrees, which came into force in 2007 the Federal law "On the migratory accounting of foreign citizens and stateless persons" (18.07.2006 No. 109-FZ) and the Federal law "On modification of the Federal law "On a legal status of foreign citizens in the Russian Federation" (from 06.01.2007 No. 2-FZ) allow to speak about the outlined tendency of liberalization of certain aspects of migration policy.

After analysis of normative legal acts of the Republic of Bashkortostan, the author comes to a conclusion that all political institutes carry out the activity in strict accordance with the all-Russian legislation. The legal acts, documents which do not correspond to the federal legislation in the sphere of migratory processes regulation were not revealed.

\section{Discussions}

There is a considerable experience in research of a migratory perspective in the Russian science. Many aspects of migratory processes came under the spotlight of scientists. At the same time there are still no fundamental works in which problems of state regulation of migratory processes in modern Russia alongside with the vital issues and consequences of migration policy, efficiency of the migratory legislation, adequacy of migratory programs to national and regional features would be considered on the basis of the politological analysis.

It is necessary to dwell separately on the researches connected with migration policy.

The functioning of structures of public administration over migratory processes is analyzed in the researches of M. L. Tyurkin (2005), T. M. Regent (1999), A. E. Shaparov (1996). In works of T. M. Regent (1999) state regulation of migratory processes is considered as a component of economic and social development strategy of the country. The main attention is paid to the analysis of the main directions of migration policy of Russia, the methodological principles and organizational forms of activity of Federal Migration Service of Russia.

Political and legal aspect of management of migratory processes in the former Soviet Union, strategic goals and problems of migration processes management, priorities in the solution of these problems, institutional structure and financial and economic instruments of realization of migration policy are covered by G. I. Starchenkov 
(1997), M. G. Arutyunov (2002), A. B.Yunusova (2005), V. I. Mukomel (2014).

Policy towards forced migrants, refugees and their rights, the issue of citizenship is analyzed by $\mathrm{O}$. N. Vorobeva, (1997), G. S. Vitkovskaya (1998), T. V. Zametina (2001), N. V. Mkrtchyan, (2003).

In Russian science the questions related to the legal framework of migration policy have found their solution. However, some aspects of the problem remained out of sight of researchers. So, despite the saved-up positive experience, it should be noted that scientific literature is presented generally by collections of conferences materials and collective monographs. There are not enough authors' monographs devoted to research of migratory processes, their features, formation of legal base of migration policy.

The questions of migration policy formation studied in this research with the account of regional aspect of migratory processes in modern Russia, in the previous researches weren't considered.

\section{Conclusion}

The research, carried out according to goals and tasks allows us to formulate the following conclusions.

1. During 1992-2010 a certain experience, both positive and negative of working with migrants was accumulated. First of all we should note the main drawbacks in the legislative sphere connected with migratory processes.

2. The existing system of migratory and administrative services of units of Federation and federal authorities in the sphere of migration shows lack of coordinated actions within the practical solution of the arising problems. It is possible to claim that the federal legislation is at the abstract and theoretical level, and in this regard there are problems in its realization: the adopted acts in practice don't find due application because legislative norms are not provided from the point of view of financing, they have different interpretations owing to what are differently understood and interpreted; lack of the thought-over mechanisms of realization gives documents declarative character; the approaches designated in the legislation don't coincide with political purpose framework.

3. The legal framework of the state migration policy is formed primarily at the federal level. There is no clear delineation of powers between the Russian Federation and its units in the regulation of migration processes and the mechanism of collaboration between state agencies.

4. The regulatory legal acts, adopted in the first half of the 90s of the XXth have lost their relevance.

5. The Russian Federation law inexistence, regulating the rights of migrants, needs some specification. Solid as a whole legislative framework does not allow to adequately reflect migration processes, proceeding in the society.

6. On analyzing the normative legal acts of the Republic of Bashkortostan, we may come to the conclusion that all political institutes of the republic carry out their activity in strict accordance with the all-Russian legislation. The legal acts, documents which do not correspond to the federal legislation in the sphere of migratory processes regulation are not revealed.

7. For the purpose of the state migration policy efficiency increase, systemic approach for migration problems solution is necessary. This includes regulation of legal framework for the whole migration flows.

\section{Recommendations}

The practical relevance of the research is that the results and conclusions can be used in management decision-making and holding specific organizational measures in order to improve the management of migration processes, as well as for the development of training courses on political science specialties: "Political regionalism", "Political management ", and in the course of "Migration policy".

\section{Acknowledgments}

The work is performed according to the Russian Government Program of Competitive Growth of Kazan Federal University.

\section{References}

Arutyunuv, M. G. (2002). Migratsionnoe zakonodatelstvo Rossiyskoy Federatsii i problemy prav cheloveka. Moskva.

Drobizheva, L. M. (1998). Sotsialnaya i kulturnaya distantsiya. Opyit mnogonatsionalnoy Rossii (pp. 286-292). Moskva.

Fayzullina A. R. (2015). Migration Policy: Characteristics of the Regional Dimension of Migration in Modern Russia (Volga Federal District). Journal of Sustainable Development, 8(4), 239-245. http://dx.doi.org/10.5539/jsd.v8n4p239 
Fayzullina, A. R. (2006). Osobennosti migratsionnyih protsessov v sovremennom rossiyskom obschestve: regionalnyiy aspekt. Etnos. Obschestvo. Tsivilizatsiya: Kuzeevskie chteniya: Materialyi mezhdunarodnoy nauchno-prakticheskoy konferentsii (pp. 95-100). Ufa: IES USC RAS.

Fayzullina, A. R. (2007). Migratsionnaya politika v sovremennoy Rossii (federalnyiy i regionalnyiy aspektyi). (Unpublished master's thesis). Bashkirskiy gosudarstvennyiy universitet, Ufa.

Law of the Russian Federation «On the state policy of the Russian Federation in respect of compatriots abroad» from 24.05 1999 № 99-Federal Law. (1999). Code of Laws of the Russian Federation, 22, 2670.

Law of the Russian Federation from 19.02.1993 № 4528-I «On Refugees». (1993). Bulletin of the Congress of People's Deputies of the Russian Federation and the Supreme Council of the Russian Federation, 12.

Law of the Russian Federation from 19.02.1993 № 4530-I «On Forced Migrants». (1993). Bulletin of the Congress of People's Deputies of the Russian Federation and the Supreme Council of the Russian Federation, 12, 427.

Law of the Russian Federation from 31.05.2002 № 62 - Federal Law "On Citizenship of the Russian Federation". (2002). Code of Laws of the Russian Federation, 22, 2031.

Mkrtchyan, N. V. (2003). Sovremennaya migratsionnaya politika Rossiyskoy Federatsii. Problemyi pravovogo regulirovaniya migratsionnyih protsessov na territorii Rossiyskoy Federatsii. Analiticheskiy vestnik Soveta Federatsii FS RF, 9(202), 24-27.

Mukomel, V. I. (2014). Ksenofobiya i migrantofobii v kontekste kulturyi doveriya. Mir Rossii, 1, 137-166.

Refugee Status Convention. (1996). Existing international law, 1(1), section "C".

Refugees and Forced Migrants Compass. (1995). Moscow, 100.

Regent, T. (1999). Gosudarstvennoe regulirovanie migratsionnyih protsessov v Rossiyskoy Federatsii. Problemyi prognozirovaniya, 1, 88-93.

Ryibakovskiy, L. L. (1987). Migratsiya naseleniya: prognozyi, faktoryi, politika. Moskva.

Shaparov, A. E. (1996). Migratsionnaya politika v sovremennoy Rossii. (Unpublished master's thesis). Moskva.

Soglashenie o pomoschi bezhentsam I vynuzhdennym peresekentsam ot 24 Sentyabrya 1993 goda. (1999). Mezhdunarodnye akty o pravakh cheloveka, 847.

Starchenkov, G. I. (1997). Trudovyie migratsii mezhdu Vostokom i Zapadom. Vtoraya polovina HH stoletiya. Moskva.

The Constitution of the Russian Federation. (2003). Codes and Laws of the Russian Federation. - St. Petersburg, $15,4,431$.

Tyurkin, M. L. (2005). Migratsionnaya sistema Rossii. Moskva: Izdatelskiy dom «Strategiya».

Vitkovskaya, G. S. (1998). Migratsiya i ryinki truda v postsovetskoy Rossii. Vyipusk 25. Moskovskiy Tsentr Karnegi. Moskva.

Vorobeva, O. N. (1997). Vyinuzhdennaya migratsiya v Rossii. Migratsiya, 1, 4-6.

Yunusova, A. B. (2005). Migratsionnyie protsessyi v Respublike Bashkortostan. Analiticheskaya spravka. Ufa: IES USC RAS.

Yunusova, A. B. (2014). Uralskiy vektor tsentralnoaziatskogo antropotoka: migrantyi v sovremennom Bashkortostane. In Rossiya $i$ stranyi Vostoka: vektoryi vzaimodeystviya $i$ sotrudnichestva (pp. 64-70). Ufa: Izdatelstvo «Bashkirskaya entsiklopediya».

Yunusova, A. B., Valeev, A. V., \& Tuzbekov, A. I. (2007). Sotsialnaya adaptatsiya migrantov v Respublike Bashkortostan, $6,35-42$.

Zametina, T. V. (Eds.). (2001). Nekotoryie problemyi sootnosheniya natsionalnoy i migratsionnoy politiki $v$ Rossiyskoy Federatsii. Migratsiya v Rossii. Problemyi pravovogo obespecheniya. Saratov.

Zayonchkovskaya, Zh. A. (Eds.). (1997). Migratsii naseleniya Rossii: Noveyshie tendentsii. Problemyi rasseleniya: istoriya i sovremennost (pp. 30-37). Moskva.

\section{Copyrights}

Copyright for this article is retained by the author(s), with first publication rights granted to the journal.

This is an open-access article distributed under the terms and conditions of the Creative Commons Attribution license (http://creativecommons.org/licenses/by/3.0/). 